\title{
PDCD5 Gene
}

National Cancer Institute

\section{Source}

National Cancer Institute. PDCD5 Gene. NCI Thesaurus. Code C115257.

This gene is involved in the positive regulation of apoptosis. 